\title{
Survey on farm practices of small-scale vegetable farmers in the Southern Philippines
}

Moises Neil V. Seriño ${ }^{1 *}$, Glorybeth Castillo and Jessa Ruales

\begin{abstract}
This study aims to survey the farm practices of small scale vegetable farmers, evaluate gender roles in farming and assess the changes in farm income of farmers engaged in integrated crop management. The respondents of the study include randomly selected small-scale vegetable farmers trained under the farmer field school (FFS) in Bohol, Leyte and Samar. Randomly selected non-FFS farmers serve as control group. Information on farm practices between non-FFS and FFS respondents are used in determining the changes in farm outcomes. Results show that FFS and non-FFS farmers mostly planted eggplant, bitter gourd, beans, sweet pepper, pechay, squash, tomato and okra. The farm areas of surveyed respondents are mostly located around 10 kilometers away from their primary market with an approximate traveling time of half an hour. During the baseline survey, FFS farmers indicated that they are mostly unsatisfied with their current vegetable production in contrast to non-FFS farmers who expressed satisfaction with their current production. However, in the follow-up survey FFS group expressed relatively higher optimism than non-FFS group in terms of their vegetable production suggesting that the project interventions were able to encourage small scale farmers to incorporate necessary improvements in their practices. For gender roles in vegetable production, men are into labor intensive tasks while women focus mostly on record keeping and monitoring sales of vegetables. Lastly, employing the method of difference in difference shows that impact of farmer field school on integrated crop management increases vegetable farm income by around PHP4,300.00 per year per farm.
\end{abstract}

Keywords: farm practices, gender roles, vegetable profitability, impact assessment

\section{INTRODUCTION}

The vegetable industry is a dynamic and large agricultural subsector in the Philippine economy. In terms of production, Philippine Statistics Authority (PSA) (2016) reported that 5.1 million tonnes of vegetables are produced in 544,000

${ }^{1}$ Department of Economics, Visayas State University

*Corresponding Author. Address: Department of Economics, Visayas State University, Visca, Baybay City, Leyte6521-APhilippines; Email:moisesneil.serino@vsu.edu.ph

DOI: $10.32945 /$ atr39sb1.2017 
hectares of land in the country in 2015. The annual average growth rate of the vegetable production only constitutes $3 \%$ from 2010-2015. In 2014-2015, net returns and net profit-cost ratio per hectare from the production decreased from 2.22 million pesos to 2.08 million pesos and 18.01 to 17.75 , respectively, which are still generally lower than the net returns of other crops such as palay and corn (PSA 2016).

The Philippines, as a tropical country with two major seasons, namely, rainy or wet season and dry season, is highly suitable for growing lowland vegetables as well as high-value semi-temperate vegetables. However, vegetable production in the country is still highly seasonal and heavily dependent on weather patterns (Armenia et al 2012). On average, around 20 typhoons occur in a year in the country which constrains vegetable farmers in producing high quality products that can increase their returns. They are also confronted with fluctuating prices, generally lowest from March to May and highest in September to December (Gonzaga et al 2013). During rainy seasons, vegetable prices tend to go up because there is a significant decrease of supply in the market (Armenia et al 2013). One of the reasons is that farmers prefer to plant other crops, such as rice and corn (GMA News 2013). Some farmers also tend to fallow their crop area due to the risk of crop failure (McClintock et al 2012). Higher transportation cost is also faced by farmers, especially in upland areas, due to occasional flooding or landslides caused by the weather conditions and poor farm-to-market roads.

Conception et al (2007) reported that there were greater quantities of vegetables harvested during the first part of the year (January to June) due to favourable cool and dry weather. During wet season (July to December) lesser quantities of vegetables, particularly lettuce, are harvested in Bukidnon and other parts of Southern Luzon when typhoons make roads impassable and damaged rain shelters (Conception et al 2007). In the study of McClintock et al (2012), information on vegetable yield distribution of tomato, eggplant, cabbage and lettuce obtained through focus group discussion showed that lower yields were harvested during wet season than dry season.

To help small scale vegetable farmers achieve higher production, the Visayas State University (VSU) together with the Australian Centre for International Agricultural Research (ACIAR) implemented a research project on integrated crop management. This research project aimed to help improve the livelihoods and food security of smallholder vegetable farmers in the Eastern Philippines. This research project aimed to address the following objectives: (1) to increase vegetable farmer profitability through integrated crop management (ICM) in Leyte, Bohol and Samar; (2) to develop component technologies for management of key insect pests and diseases in Leyte, Bohol and Samar; (3) to develop a commercial clean seed potato production system; (4) to develop component technologies for management of key agronomic constraints for each target site in Leyte, Bohol and Samar; and (5) to build capacity in ICM skills and research capacity in Leyte, Bohol and Samar. The outcomes of this project were achieved by training at least 1,000 farmers in the Southern Philippines.

In relation to this collaborative research project, the East-west Seed Company and Landcare Inc. were tasked to conduct a farmer field school (FFS). The objective of the farmer field school was to teach and train vegetables farmers on the new and better ways of producing vegetables. A baseline survey was conducted in early 
2015 and follow-up survey were conducted in mid-2017. The aim of the survey is to describe the farm practices and techniques of the small-scale vegetable farmers before and after project intervention. Randomly selected non-FFS farmers were also surveyed to serve as a control group for this research project. The objectives of the baseline and follow up survey were: (1) to describe the socio-economic profile of small-scale vegetable farmers; (2) to determine and compare the differences in vegetable production, marketing practices and topographical conditions of the nonFFS and FFS farmer respondents; (3) to evaluate the role of men and women in vegetable farming; and (4) to assess the impact of farmer field school on the profitability of small-scale vegetable production.

\section{METHODOLOGY}

\section{The Project Site}

The farmer field school (FFS) was conducted in three provinces in the Eastern Philippines namely Leyte, Samar and Bohol. The vegetable farmers trained by Eastwest Seeds Company and Landcare Philippines Inc. were mostly located in remote and mountainous areas. These farmers are far from the municipal centers which hinders the flow of information in terms of new innovations or new techniques in vegetable production. The farmers trained by the East-west seeds and Landcare make up the population of the FFS group. To have a point of comparison, farmers not trained under the FFS were also randomly selected. The location of non-FFS farmers was relatively far from FFS group to avoid a spill-over effect. Spill-over effect is a situation wherein farmers not under the program will be made aware of what the farmers under the program learned from the farmer field school. Though spill-over effect cannot be totally controlled for, the strategic distance between the two groups can hinder a quick spill of information. In this case, we can analyze the impact of the farmer field school on the practices of small-scale vegetable farmers. Figure 1 shows the location of the FFS and non-FFS farmers.

\section{Sampling Scheme for FFS and non-FFS respondents}

The targeted number of farmers trained under FFS was 900 farmer participants which were divided into 400 farmers in Bohol, 300 farmers in Leyte and 200 farmers in Samar. From this targeted number of farmers, Slovin's formula was used to determine the appropriate sample size for the baseline survey. The sample size was computed as follows:

$$
\mathrm{n}=\mathrm{N} /\left(1+\mathrm{Ne}^{2}\right)
$$

where:

$$
\begin{aligned}
& n=\text { is the required sample size } \\
& N=\text { is the population } \\
& e=\text { is the margin of error }
\end{aligned}
$$




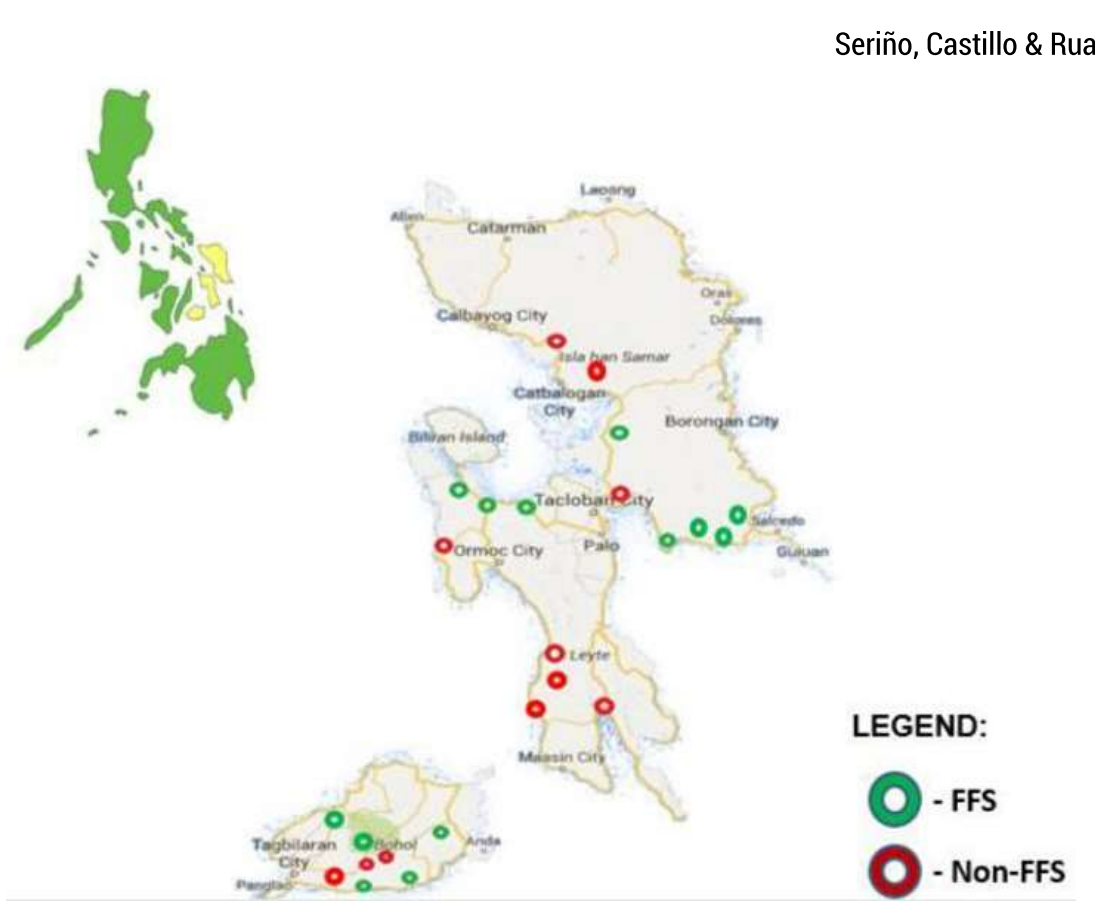

Figure 1. The area covered of the survey

Using the above formula and with an assumed $6 \%$ margin of error, the required sample for the FFS farmers was 212 respondents. Due to some adjustment of the number of FFS participants including those involved in pretesting, we surveyed a total of $221 \mathrm{FFS}$ farmers. The same respondents were surveyed to obtain follow-up information necessary to assess the impact of the farmer field school. The baseline survey was conducted in 2015 and the follow up survey was conducted in 2017.

For the non-FFS group, thirty farmers from each province was purposely selected to serve as control group. The sample size of 30 farmers was the usual sample size for small samples. This made the total sample size of non-FFS respondents equal to 90 farmers. The respondents were taken from the list provided by the municipal agriculture office (MAO) of the selected municipalities. From the list, we randomly selected 30 farmers from each province who were situated relatively far from the FFS group but had similar socio-economic characteristics with the FFS groups. The assumption was that before FFS training, the practices of farmers in both groups were relatively similar. 
Survey on farm practices of small-scale vegetable farmers

Table 1 presents the summary of sample size for both FFS and non-FFS farmers in Bohol, Leyte and Samar. The baseline and follow-up survey covered a total of 221 FFS farmers and 90 non-FFS farmers. In total, 311 respondents were covered in survey.

Table 1. Distribution of FFS and Non-FFS respondents

\begin{tabular}{lcccc}
\hline \multicolumn{1}{c}{ Item } & Bohol & Leyte & Samar & Total \\
\hline No. of FFS respondents $(\mathrm{n})$ & 97 & 48 & 76 & 221 \\
No. of Non-FFS Respondents & 30 & 30 & 30 & 90 \\
Total Respondents & 127 & 78 & 106 & 311 \\
& & & & \\
\hline
\end{tabular}

\section{Survey Design}

It was assumed that before the program intervention or before the farmer field school, these two group of farmers were relatively similar in their farm practices. After the program, we expected that farmers trained under the FFS would acquire more skills and knowledge and would apply this into their vegetable production. This implied that FFS farmers would be better off in comparison to farmers who were not able to participate in the FFS. Though there would be changes across time, in the long run we expect farmers to benefit more from the training. In this set-up, the possible impact of the project can be extracted. Hence, baseline information before the program intervention is needed and follow-up survey at the end of the project were obtained. Figure 2 shows the assumed impact on the farm practices of smallscale vegetable farmers who were trained under FFS. To estimate the impact, the method of difference in difference was used.

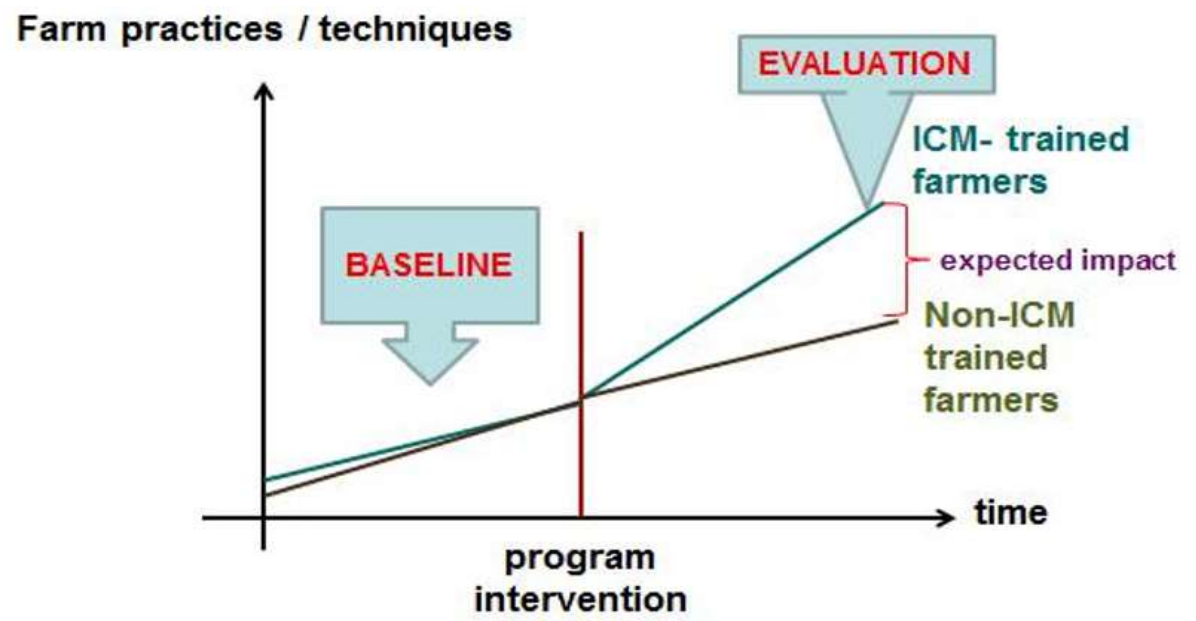

Figure 2. Assumption of the impact of farmer field school 


\section{Data Collection}

A detailed questionnaire on the farm practices including farmers' sociodemographic information was developed. The questionnaire was pre-tested to ensure its applicability and make sure questions were formulated that the farmers can comprehend. Local enumerators were hired to conduct field interviews among identified respondents. Prior to the actual field interviews, the enumerators were oriented with the questionnaire for them to be familiar with it.

\section{Data Analysis}

Data tabulation in this study was accomplished using the Statistical Package for Social Sciences (SPSS). Descriptive analysis was carried out to compare the different practices of the FFS and non-FFS farmers. In determining the impact of farmers' field school, the method of difference in difference was used. The measured impact can be taken as an immediate impact given that the duration considered is only two years.

\section{RESULTS AND DISCUSSION}

This section discusses the production and marketing practices of the sample household respondents for both the non-FFS and FFS farmers. Awareness in protected cultivation technology and the topographical condition of farms cultivated were surveyed. In addition, gender roles in farming were also evaluated.

\section{Baseline Results}

\section{Vegetable production and practices}

Table 2 shows the variety of vegetables planted by non-FFS and FFS respondents. The most commonly planted vegetable crop is eggplant as reported by $64.4 \%$ of the non-FFS and $61.0 \%$ of the FFS farmers. Beans which include string beans, baguio beans and pole beans is the second most planted crop for both nonFFS and FFS. Next to strings beans are bitter gourd, squash and sweet pepper. Other commonly planted vegetables include pechay, tomato, okra or lady fingers. Both FFS and non-FFS participants plant the same eight crops (Table 2).

Table 2. Crops planted by surveyed farmer respondents

\begin{tabular}{llcccccc}
\hline \multirow{2}{*}{ Crops Planted } & \multicolumn{2}{c}{ Non-FFS } & \multicolumn{2}{c}{ FFS } & \multicolumn{2}{c}{ Total } \\
\cline { 2 - 7 } & $\mathrm{n}$ & $\%$ & $\mathrm{n}$ & $\%$ & $\mathrm{n}$ & $\%$ \\
\hline Eggplant & 58 & 64.4 & 105 & 61.0 & 163 & 62.2 \\
Beans & 39 & 43.3 & 68 & 39.5 & 107 & 40.8 \\
Bitter Gourd & 33 & 36.7 & 64 & 37.2 & 97 & 37.0 \\
Squash & 24 & 26.7 & 61 & 35.5 & 85 & 32.4 \\
Sweet Potato & 19 & 21.1 & 57 & 33.1 & 76 & 29.0 \\
Pechay & 33 & 36.7 & 33 & 19.2 & 66 & 25.2 \\
\hline
\end{tabular}


Survey on farm practices of small-scale vegetable farmers

Table 2 continued

\begin{tabular}{lrrrrrr}
\hline \multirow{2}{*}{ Crops Planted* } & \multicolumn{2}{c}{ Non-FFS } & \multicolumn{3}{c}{ FFS } & \multicolumn{2}{c}{ Total } \\
\cline { 2 - 6 } & $\mathrm{n}$ & $\%$ & $\mathrm{n}$ & $\%$ & $\mathrm{n}$ & $\%$ \\
\hline Tomato & 20 & 22.2 & 45 & 26.2 & 65 & 24.8 \\
Okra (Lady fingers) & 23 & 25.6 & 30 & 17.4 & 53 & 20.2 \\
Cucumber & 14 & 15.6 & 9 & 5.2 & 23 & 8.8 \\
Bottle Gourd & 10 & 11.1 & 10 & 5.8 & 20 & 7.6 \\
Sibuyas (Onions) & 2 & 2.2 & 12 & 7.0 & 14 & 5.3 \\
Sili Espada (Cayenne Pepper) & 2 & 2.2 & 8 & 4.7 & 10 & 3.8 \\
Sponge Gourd & 6 & 6.7 & 4 & 2.3 & 10 & 3.8 \\
Water Spinach & 3 & 3.3 & 4 & 2.3 & 7 & 2.7 \\
Ginger & 3 & 3.3 & 4 & 2.3 & 7 & 2.7 \\
Patola (Zuchini) & 1 & 1.1 & 4 & 2.3 & 5 & 1.9 \\
Monggos (Mung Bean) & 1 & 1.1 & 3 & 1.7 & 4 & 1.5 \\
Chayote & 0 & 0.0 & 1 & .6 & 1 & .4 \\
Alugbati (Malabar nightshade) & 0 & 0.0 & 1 & .6 & 1 & .4 \\
Mustasa (Mustard) & 0 & 0.0 & 1 & .6 & 1 & .4 \\
\hline *multiple response & & & & & &
\end{tabular}

*multiple response

Methods of Raising Seedlings. Tables 3.1 and Table 3.2 show the different methods of raising the seedlings for the top 8 vegetable crops (eggplant, bitter gourd, beans, sweet pepper, pechay, squash, tomato \& okra). Raising seedlings in the seed box then pricking it to a seedling tray before transplanting it to the field is the most common method of raising seedlings for tomato (35.4\%), sweet pepper (43.4\%), eggplant (30.6\%) and pechay (39.1\%). In the case of bitter gourd, beans, okra and squash direct seeding is commonly practiced.

Table 3.1 Methods of raising seedlings by crops

\begin{tabular}{|c|c|c|c|c|c|c|c|c|}
\hline \multirow{2}{*}{ Methods of Raising Seedlings } & \multicolumn{2}{|c|}{ Tomato } & \multicolumn{2}{|c|}{ Sweet pepper } & \multicolumn{2}{|c|}{ Eggplant } & \multicolumn{2}{|c|}{ Bitter gourd } \\
\hline & $\mathrm{N}$ & $\%$ & $n$ & $\%$ & $n$ & $\%$ & $\mathrm{n}$ & $\%$ \\
\hline Direct Seeding & 3 & 4.6 & 3 & 3.9 & 11 & 6.9 & 42 & 43.3 \\
\hline Seed box then prick to seedling tray & 23 & 35.4 & 33 & 43.4 & 49 & 30.6 & 10 & 10.3 \\
\hline Direct Seed into Seedling tray & 13 & 20.0 & 16 & 21.1 & 41 & 25.6 & 19 & 19.6 \\
\hline $\begin{array}{l}\text { Bare Root transplant from seed box } \\
\text { to the field }\end{array}$ & 6 & 9.2 & 7 & 9.2 & 13 & 8.1 & 7 & 7.2 \\
\hline Lukong & 14 & 21.5 & 6 & 7.9 & 24 & 15.0 & 9 & 9.3 \\
\hline Seedbox then transplant to field & 1 & 1.5 & 1 & 1.3 & 3 & 1.9 & 1 & 1.0 \\
\hline $\begin{array}{l}\text { Seed box then prick to lukong then } \\
\text { transplant }\end{array}$ & 2 & 3.1 & 4 & 5.3 & 10 & 6.2 & 2 & 2.1 \\
\hline Bigti & 0 & 0.0 & 0 & 0.0 & 0 & 0.0 & 0 & 0.0 \\
\hline $\begin{array}{l}\text { Ragdoll to seedling tray then } \\
\text { transplanted to the field }\end{array}$ & 2 & 3.1 & 1 & 1.3 & 2 & 1.2 & 3 & 3.1 \\
\hline Seedbed then transplant & 1 & 1.5 & 3 & 3.9 & 3 & 1.9 & 2 & 2.1 \\
\hline Seed bag then transplant & 0 & 0.0 & 0 & 0.0 & 2 & 1.2 & 1 & 1.0 \\
\hline $\begin{array}{l}\text { Seed box then prick to seedling bag } \\
\text { then transplant }\end{array}$ & 0 & 0.0 & 0 & 0.0 & 1 & 0.6 & 0 & 0.0 \\
\hline
\end{tabular}


Seriño, Castillo \& Ruales

Table 3.2 Methods of raising seedlings by crops

\begin{tabular}{|c|c|c|c|c|c|c|c|c|}
\hline \multirow{2}{*}{ Methods of Raising Seedlings } & \multicolumn{2}{|c|}{ Pechay } & \multicolumn{2}{|c|}{ Beans } & \multicolumn{2}{|c|}{ Okra } & \multicolumn{2}{|c|}{ Squash } \\
\hline & $\mathrm{n}$ & $\%$ & $\mathrm{n}$ & $\%$ & $\mathrm{~N}$ & $\%$ & $n$ & $\%$ \\
\hline Direct Seeding & 9 & 14.1 & 97 & 91.5 & 41 & 82.0 & 63 & 75.9 \\
\hline $\begin{array}{l}\text { Seed box then prick to seedling } \\
\text { tray }\end{array}$ & 25 & 39.1 & 2 & 1.9 & 3 & 6.0 & 3 & 3.6 \\
\hline Direct Seed into Seedling tray & 7 & 10.9 & 2 & 1.9 & 2 & 4.0 & 6 & 7.2 \\
\hline $\begin{array}{l}\text { Bare Root transplant from seed } \\
\text { box to the field }\end{array}$ & 8 & 12.5 & 2 & 1.9 & 1 & 2.0 & 2 & 2.4 \\
\hline Lukong & 4 & 6.2 & 2 & 1.9 & 2 & 4.0 & 6 & 7.2 \\
\hline $\begin{array}{l}\text { Seed box then transplant to the } \\
\text { field }\end{array}$ & 4 & 6.2 & 1 & 0.9 & 1 & 2.0 & 0 & 0.0 \\
\hline $\begin{array}{l}\text { Seedbox then prick to lukong then } \\
\text { transplant }\end{array}$ & 2 & 3.1 & 0 & 0.0 & 0 & 0.0 & 0 & 0.0 \\
\hline Bigti & 1 & 1.6 & 0 & 0.0 & 1 & 2.0 & 1 & 1.2 \\
\hline Seedbed then transplant & 4 & 6.2 & 1 & 0.9 & 0 & 0.0 & 2 & 2.4 \\
\hline Seed bag then transplant & 0 & 0.0 & 0 & 0.0 & 0 & 0.0 & 2 & 2.6 \\
\hline
\end{tabular}

With regards to land tilling, majority of the vegetable farmers till their land. Roughly $60 \%$ of the farmers who grow tomato, sweet pepper, eggplant and bitter gourd use draft-animal powered tilling (eg, carabao). This include plowing and harrowing the area to be planted with vegetables. For pechay, okra, beans and squash, farmers opt to use farm/hand tools in shoveling, hoeing and raking the area. Relatively, only a small proportion of the farmer respondents use machines during land preparation (Table 4.1 \& Table 4.2).

Table 4.1 Distribution of respondents according to methods of tilling by crops

\begin{tabular}{lcccccccc}
\hline \multirow{2}{*}{ Methods of Tilling* } & \multicolumn{2}{c}{ Tomato } & \multicolumn{2}{c}{ Sweet pepper } & \multicolumn{2}{c}{ Eggplant } & \multicolumn{2}{c}{ Bitter gourd } \\
\cline { 2 - 9 } & $\mathrm{n}$ & $\%$ & $\mathrm{n}$ & $\%$ & $\mathrm{n}$ & $\%$ & $\mathrm{n}$ & $\%$ \\
\hline Human powered tilling & 35 & 54.7 & 28 & 37.3 & 84 & 54.2 & 45 & 48.9 \\
Draft-animal powered & 40 & 62.5 & 48 & 64.0 & 94 & 60.6 & 55 & 59.8 \\
Mechanized Work & 0 & 0.0 & 0 & 0.0 & 1 & 0.6 & 0 & 0.0 \\
\hline *multiple response & & & & & & & &
\end{tabular}

Table 4.2 Distribution of respondents according to methods of tilling by crops

\begin{tabular}{|c|c|c|c|c|c|c|c|c|}
\hline \multirow{2}{*}{ Methods of Tilling* } & \multicolumn{2}{|c|}{ Pechay } & \multicolumn{2}{|c|}{ Beans } & \multicolumn{2}{|c|}{ Okra } & \multicolumn{2}{|c|}{ Squash } \\
\hline & $\mathrm{n}$ & $\%$ & $\mathrm{n}$ & $\%$ & $\mathrm{n}$ & $\%$ & $\mathrm{n}$ & $\%$ \\
\hline Human powered tilling & 41 & 68.3 & 58 & 58.6 & 32 & 68.1 & 45 & 57.7 \\
\hline Draft-animal powered & 27 & 45.0 & 55 & 55.6 & 23 & 48.9 & 42 & 53.8 \\
\hline Mechanized Work & 2 & 3.3 & 0 & 0.0 & 1 & 2.1 & 1 & 1.3 \\
\hline
\end{tabular}


Survey on farm practices of small-scale vegetable farmers

Majority of non-FFS and FFS farmers plant one (1) plant per hill and two (2) rows per plot. For pechay, majority of the farmers plant five (5) rows in a plot and one (1) plant per hill. For squash, both farmers plant one (1) row in a plot and one (1) plant per hill (Table 5).

Table 5. Planting practices per crop

\begin{tabular}{lcccc}
\hline \multirow{3}{*}{ Crop Planted } & \multicolumn{2}{c}{ Non-FFS } & \multicolumn{2}{c}{ FFS } \\
\cline { 2 - 5 } & $\begin{array}{c}\text { Number of rows } \\
\text { in a plot }\end{array}$ & $\begin{array}{c}\text { Number of plants } \\
\text { per hill }\end{array}$ & $\begin{array}{c}\text { Number of rows } \\
\text { in a plot }\end{array}$ & $\begin{array}{c}\text { Number of plants } \\
\text { per hill }\end{array}$ \\
\cline { 2 - 5 } & Mode & Mode & Mode & Mode \\
\hline Tomato & 2 & 1 & 2 & 1 \\
Sweet Pepper & 2 & 1 & 2 & 1 \\
Eggplant & 2 & 1 & 2 & 1 \\
Ampalaya & 1 & 1 & 2 & 1 \\
Pechay & 5 & 1 & 5 & 1 \\
Beans & 2 & 1 & 1 & 1 \\
Okra & 1 & 1 & 2 & 2 \\
Squash & 1 & 1 & 1 & 1 \\
\hline
\end{tabular}

With few exceptions, most of the vegetable crops are planted on the first quarter of the year (sweet pepper, bitter gourd, okra \& squash). Majority of the farmers plant eggplant and beans on the second quarter of the year specifically on the month of June. Tomato is mostly planted on August. Moreover, pechay is planted several times throughout the year (Figure 3 ).

\begin{tabular}{|l|l|l|l|l|l|l|l|l|l|l|l|l|}
\hline Crops planted & Jan & Feb & Mar & Apr & May & Jun & Jul & Aug & Sep & Oct & Nov & Dec \\
\hline Tomato & & & & & & & & & & & & \\
\hline Sweet pepper & & & & & & & & & & & & \\
\hline Eggplant & & & & & & & & & & & & \\
\hline Ampalaya & & & & & & & & & & & & \\
\hline Pechay & & & & & & & & & & & & \\
\hline Beans & & & & & & & & & & & & \\
\hline Okra & & & & & & & & & & & & \\
\hline Squash & & & & & & & & & & & \\
\hline
\end{tabular}

Figure 3. Seasonal variation in planting (mode)

Weeds have to be managed in any cropping systems. Roughly $87.2 \%$ of the farmers responded that there is a problem on weed infestation in their farm areas (Table 6). As to weed management, manual removal (97.2\%) is the most common way of controlling weeds. Others also employ mulching (9.3\%), application of herbicides (3.2\%) and plowing (2.4\%). Animal grazing and under brushing are only practiced in non-FFS areas while one FFS farmer practices kaingin method to control weeds. 
Seriño, Castillo \& Ruales

Table 6. Problem on weed infestation in the farm area

\begin{tabular}{lcrrrrr}
\hline \multirow{2}{*}{ Problem } & \multicolumn{2}{c}{ Non-FFS } & \multicolumn{2}{c}{ FFS } & \multicolumn{3}{c}{ Total } \\
\cline { 2 - 6 } & $\mathrm{N}$ & $\%$ & $\mathrm{~N}$ & \multicolumn{1}{c}{$\%$} & $\%$ \\
\hline Yes & 77 & 86.5 & 148 & 87.6 & 225 & 87.2 \\
No & 12 & 13.5 & 21 & 12.4 & 33 & 12.8 \\
Total & 89 & 100.0 & 169 & 100.0 & 258 & 100.0 \\
\hline \multicolumn{2}{l}{ Ways to control weed infestation* } & & & & & \\
\hline Manual Removal & 84 & 95.5 & 157 & 98.1 & 241 & 97.2 \\
Mulching & 8 & 9.1 & 15 & 9.4 & 23 & 9.3 \\
Animal grazing & 2 & 2.3 & 0 & 0.0 & 2 & 0.8 \\
Use of herbicides & 2 & 2.3 & 6 & 3.8 & 8 & 3.2 \\
Kaingin & 0 & 0.0 & 1 & 0.6 & 1 & 0.4 \\
Plowing & 4 & 4.5 & 2 & 1.2 & 6 & 2.4 \\
Under brushing & 1 & 1.1 & 0 & 0.0 & 1 & 0.4 \\
\hline
\end{tabular}

*multiple response

\section{Marketing Practices}

The farmers have varied options in marketing their produce. Table 7 shows the primary market outlet of vegetable farmers. Results show that $47.7 \%$ of respondents sell their vegetables to nearby market places. Farmers also sell their vegetables to their neighbors (39.5\%) and to traders (18.9\%). This market outlet is consistent for both non-FFS and FFS respondents. Other unconventional product outlet for vegetable farmers includes: selling at restaurants, local stores/shop and to the Department of Agriculture. Very few (3.7\%) indicated that their primary market outlet for vegetable is through family consumption.

Table 7. Primary market outlet for vegetables

\begin{tabular}{lrrrrrr}
\hline \multirow{2}{*}{ Primary product outlet* } & \multicolumn{2}{c}{ Non-FFS } & \multicolumn{2}{c}{ FFS } & \multicolumn{2}{c}{ Total } \\
\cline { 2 - 7 } & $\mathrm{n}$ & $\%$ & $\mathrm{n}$ & $\%$ & $\mathrm{n}$ & $\%$ \\
\hline Local market & 41 & 46.6 & 75 & 48.4 & 116 & 47.7 \\
Neighbors /relatives & 34 & 38.6 & 62 & 40.0 & 96 & 39.5 \\
Traders & 18 & 20.5 & 28 & 18.1 & 46 & 18.9 \\
Regular buyers & 14 & 15.9 & 26 & 16.8 & 40 & 16.5 \\
Interlinked market outlet & 3 & 3.4 & 4 & 2.6 & 7 & 2.9 \\
Buying station & 6 & 6.8 & 0 & 0.0 & 6 & 2.5 \\
Store & 0 & 0.0 & 6 & 3.9 & 6 & 2.5 \\
Family consumption & 1 & 1.1 & 8 & 5.2 & 9 & 3.7 \\
Department of Agriculture & 1 & 1.1 & 1 & 0.6 & 2 & 0.8 \\
Restaurant & 1 & 1.1 & 0 & 0.0 & 1 & 0.6 \\
\hline *multiple response & & & & & &
\end{tabular}

The average distance of farms of the non-FFS and FFS respondents to the market outlets is close to $9 \mathrm{~km}$ with an estimated travelling time of around $26 \mathrm{~min}$ (Table 8). 
Survey on farm practices of small-scale vegetable farmers

Table 8. Distance from farm to market

\begin{tabular}{lrrr}
\hline \multirow{2}{*}{\multicolumn{1}{c}{ Item }} & Non-FFS & \multicolumn{1}{c}{ FFS } & Total \\
\cline { 2 - 4 } & Mean & Mean & Mean \\
\hline Distance of market from production point $(\mathrm{km})$ & 8.28 & 9.02 & 8.65 \\
Travel time (minutes) & 26.22 & 24.21 & 25.21 \\
\hline
\end{tabular}

\section{Farmer's Perception on Production}

More than half $(51.7 \%)$ of the non-FFS are satisfied with their current production output. However, only $31.9 \%$ of the FFS express satisfaction on their current outputs. Table 9 shows that there is higher percentage of FFS farmers who are not satisfied with their current production output as compared to the non-FFS group. If farmer field school will have a positive impact on farmer's production in the long run, we expect that in the coming years the satisfaction of farmers output among the FFS group will increase.

On the average, about $47 \%$ of the farmer respondents perceive that there will be a slight increase in their vegetable production output in the next five years and only $4.4 \%$ perceive that the production output on the next five years will decrease a little (Table 10). Higher percentage of FFS farmers have positive perception regarding on the production output for the next five years than non-FFS participants. This is an indication that the FFS group are more optimistic in their production. This could be due to the interventions that the project plans to implement.

Table 9. Distribution of respondents according to the degree of satisfaction for current production

\begin{tabular}{lrrrrrr}
\hline \multirow{2}{*}{ Satisfaction level } & Non-FFS & \multicolumn{3}{c}{ FFS } & \multicolumn{3}{c}{ Total } \\
\cline { 2 - 7 } & \multicolumn{1}{c}{$\mathrm{n}$} & \multicolumn{1}{c}{$\%$} & $\mathrm{n}$ & \multicolumn{1}{c}{$\%$} & \multicolumn{1}{c}{$\mathrm{n}$} & \multicolumn{1}{c}{$\%$} \\
\hline Not very satisfied & 1 & 1.1 & 6 & 3.6 & 7 & 2.7 \\
Not Satisfied & 17 & 19.1 & 54 & 32.5 & 71 & 27.8 \\
Neutral & 16 & 18.0 & 38 & 22.9 & 54 & 21.2 \\
Satisfied & 46 & 51.7 & 53 & 31.9 & 99 & 38.8 \\
Very Satisfied & 9 & 10.1 & 15 & 9.0 & 24 & 9.4 \\
Total & 89 & 100.0 & 166 & 100.0 & 255 & 100.0 \\
\hline
\end{tabular}

Table 10. Distribution of respondents according to perception on production output in the next five years

\begin{tabular}{lcrrrrr}
\hline \multirow{2}{*}{ Perception } & \multicolumn{2}{c}{ Non-FFS } & \multicolumn{3}{c}{ FFS } & \multicolumn{3}{c}{ Total } \\
\cline { 2 - 6 } & \multicolumn{1}{c}{$\mathrm{n}$} & \multicolumn{1}{c}{$\%$} & $\mathrm{n}$ & \multicolumn{1}{c}{$\%$} & $\mathrm{n}$ & $\%$ \\
\hline Will decrease considerably & 0 & 0.0 & 3 & 1.8 & 3 & 1.2 \\
Will decrease a little & 5 & 5.7 & 6 & 3.7 & 11 & 4.4 \\
Same & 23 & 26.4 & 15 & 9.1 & 38 & 15.1 \\
Will improve a little & 41 & 47.1 & 77 & 47.0 & 118 & 47.0 \\
Will improve considerably & 18 & 20.7 & 63 & 38.4 & 81 & 32.3 \\
Total & 87 & 100.0 & 164 & 100.0 & 251 & 100.0 \\
\hline
\end{tabular}


Seriño, Castillo \& Ruales

\section{Highlights of the Follow-Up Survey}

The baseline survey was conducted in early 2015 . We conducted the follow-up survey in the mid-2017. In the follow-up survey, we ensure that the surveyed respondents are the same respondents during the baseline survey. With this mechanism, we can monitor the changes on farm practices of the respondents. However, there were a few respondents who were not available during the conduct of the follow up survey. During the baseline survey a total of 311 respondents were surveyed. In the follow-up survey, we were able to include only 272 respondents representing around $88 \%$ of the original respondents. Table 11 shows the different reasons for the non-inclusion of 39 farmer respondents in the follow up survey.

Table 11. Reasons for non-inclusion in the follow-up survey

\begin{tabular}{lc}
\hline Reasons why other farmers were not included & $\mathrm{n}$ \\
\hline No longer in the barangay (Migrated or worked to other place) & 15 \\
Security threat and Accessibility (armed conflict) & 8 \\
Not available during the time of the survey & 16 \\
Total & 39 \\
\hline
\end{tabular}

\section{Vegetable Production}

Table 12 shows the baseline and follow-up results among FFS and non-FFS respondents. Results show that the major crop grown during the baseline and follow up survey is eggplant as reported by $59.7 \%$ for non-FFS and $65.6 \%$ for FFS farmers. However, there were changes in the preference of vegetables planted during the follow up survey. The second most planted crop for both non-FFS and FFS is sweet pepper (47.3\%) followed by bitter gourd (36.0\%). Beans which was ranked second during the baseline survey has now been ranked $4^{\text {th }}$ among the top 8 crops during the follow up survey.

Table 12. Major crops planted by respondents

\begin{tabular}{|c|c|c|c|c|c|c|c|c|c|c|c|c|}
\hline \multirow{3}{*}{ Crops* } & \multicolumn{6}{|c|}{ Baseline } & \multicolumn{6}{|c|}{ Follow-Up } \\
\hline & \multicolumn{2}{|c|}{ Non-FFS } & \multicolumn{2}{|c|}{ FFS } & \multicolumn{2}{|c|}{ Total } & \multicolumn{2}{|c|}{ Non-FFS } & \multicolumn{2}{|c|}{ FFS } & \multicolumn{2}{|c|}{ Total } \\
\hline & $n$ & $\%$ & $\mathrm{n}$ & $\%$ & $\mathrm{n}$ & $\%$ & $n$ & $\%$ & $\mathrm{n}$ & $\%$ & $\mathrm{n}$ & $\%$ \\
\hline Eggplant & 58 & 64.4 & 105 & 61.0 & 163 & 62.2 & 37 & 59.7 & 105 & 65.6 & 142 & 64.0 \\
\hline Beans & 39 & 43.3 & 68 & 39.5 & 107 & 40.8 & 22 & 35.5 & 43 & 26.9 & 65 & 29.3 \\
\hline $\begin{array}{l}\text { Bitter } \\
\text { Gourd }\end{array}$ & 33 & 36.7 & 64 & 37.2 & 97 & 37.0 & 20 & 32.3 & 60 & 37.5 & 80 & 36.0 \\
\hline Squash & 24 & 26.7 & 61 & 35.5 & 85 & 32.4 & 8 & 12.9 & 31 & 19.4 & 39 & 17.6 \\
\hline $\begin{array}{l}\text { Sweet } \\
\text { Pepper }\end{array}$ & 19 & 21.1 & 57 & 33.1 & 76 & 29 & 24 & 38.7 & 81 & 50.6 & 105 & 47.3 \\
\hline Pechay & 33 & 36.7 & 33 & 19.2 & 66 & 25.2 & 19 & 30.6 & 20 & 12.5 & 39 & 17.6 \\
\hline Tomato & 20 & 22.2 & 45 & 26.2 & 65 & 24.8 & 11 & 17.7 & 42 & 26.3 & 53 & 23.9 \\
\hline Okra & 23 & 25.6 & 30 & 17.4 & 53 & 20.2 & 13 & 21 & 22 & 13.8 & 35 & 15.8 \\
\hline
\end{tabular}


Survey on farm practices of small-scale vegetable farmers

\section{Awareness of Protected Cultivation}

Table 13 reveals that during the follow-up survey, more than half $(63.0 \%)$ of the respondents are aware of the technology on protected cultivation (68.4\% of FFS group \& $52.1 \%$ among non-FFS group). This is an improvement as compared to the baseline situation. The information pertaining to this technology is mostly learned through training, seminars and forums attended (63.7\%). Others learnt through field visits (19.0\%), farmer field school (14.3\%) and from agricultural technicians (11.3\%) (Table 14).

The follow up survey shows that about three-fourths of the farmers (78\%) are still willing to adopt the technology (among which $80.6 \%$ of FFS farmers \& $70.2 \%$ of non-FFS farmers) (Table 15). Although around $80 \%$ of the FFS respondents indicated that they are willing to adopt protective cultivation, only very few $(10.5 \%)$ adopted the technology. Result shows that there is still a higher percentage of who are not currently adopting the technology.

Table 13. Awareness on growing crops under protective cultivation

\begin{tabular}{|c|c|c|c|c|c|c|c|c|c|c|c|c|}
\hline \multirow{3}{*}{ Awareness } & \multicolumn{6}{|c|}{ Baseline } & \multicolumn{6}{|c|}{ Follow up } \\
\hline & \multicolumn{2}{|c|}{ Non-FFS } & \multicolumn{2}{|c|}{ FFS } & \multicolumn{2}{|c|}{ Total } & \multicolumn{2}{|c|}{ Non-FFS } & \multicolumn{2}{|c|}{ FFS } & \multicolumn{2}{|c|}{ Total } \\
\hline & $n$ & $\%$ & $n$ & $\%$ & $\mathrm{n}$ & $\%$ & $\mathrm{n}$ & $\%$ & $\mathrm{n}$ & $\%$ & $\mathrm{n}$ & $\%$ \\
\hline Aware & 39 & 43.3 & 98 & 45 & 137 & 44.5 & 38 & 52.1 & 132 & 68.4 & 170 & 63.9 \\
\hline Not Aware & 51 & 56.7 & 120 & 55 & 171 & 55.5 & 35 & 47.9 & 61 & 31.6 & 96 & 36.1 \\
\hline Total & 90 & 100 & 218 & 100 & 308 & 100 & 73 & 100 & 193 & 100 & 266 & 100 \\
\hline
\end{tabular}

Table 14. Source of information about protective cultivation

\begin{tabular}{|c|c|c|c|c|c|c|}
\hline \multirow{3}{*}{ Source* } & \multicolumn{6}{|c|}{ Follow-Up } \\
\hline & \multicolumn{2}{|c|}{ Non-FFS } & \multicolumn{2}{|c|}{ FFS } & \multicolumn{2}{|c|}{ Total } \\
\hline & $n$ & $\%$ & $\mathrm{n}$ & $\%$ & $\mathrm{n}$ & $\%$ \\
\hline Through training, seminars and forums attended & 24 & 64.9 & 83 & 63.4 & 107 & 63.7 \\
\hline Agricultural technicians & 7 & 18.9 & 12 & 9.2 & 19 & 11.3 \\
\hline Through Field Visits & 5 & 13.5 & 27 & 20.6 & 32 & 19 \\
\hline Farmer Field School & 1 & 2.7 & 23 & 17.6 & 24 & 14.3 \\
\hline Other farmers & 5 & 13.5 & 9 & 6.9 & 14 & 8.3 \\
\hline TV Program & - & - & 1 & 0.8 & 1 & 0.6 \\
\hline internet & - & - & 2 & 1.5 & 2 & 1.2 \\
\hline Saw it in the other Barangay & - & - & - & - & - & - \\
\hline From other countries & - & - & - & - & - & - \\
\hline Saw it along the way & 1 & 2.7 & 2 & 1.5 & 3 & 1.8 \\
\hline Saw it in the Poblacion garden & - & - & 2 & 1.5 & 2 & 1.2 \\
\hline
\end{tabular}


Seriño, Castillo \& Ruales

Table 15. Willingness to adopt protective cultivation

\begin{tabular}{|c|c|c|c|c|c|c|}
\hline \multirow{3}{*}{ Willingness } & \multicolumn{6}{|c|}{ Follow-Up } \\
\hline & \multicolumn{2}{|c|}{ Non-FFS } & \multicolumn{2}{|c|}{ FFS } & \multicolumn{2}{|c|}{ Total } \\
\hline & $n$ & $\%$ & $n$ & $\%$ & $n$ & $\%$ \\
\hline Willing & 33 & 70.2 & 112 & 80.6 & 145 & 78.0 \\
\hline Not-Willing & 14 & 29.8 & 27 & 19.4 & 41 & 22.0 \\
\hline Total & 47 & 100.0 & 139 & 100.0 & 186 & 100.0 \\
\hline Adoption & & & & & & \\
\hline Adopt & 8 & 18.2 & 13 & 10.5 & 21 & 12.5 \\
\hline Did not Adopt & 36 & 81.8 & 111 & 89.5 & 147 & 87.5 \\
\hline Total & 44 & 100.0 & 124 & 100.0 & 168 & 100.0 \\
\hline
\end{tabular}

Table 16 shows the different reasons why greater portion of willing farmers are not actually adopting the protected cropping technology. The follow up survey shows that the cost of constructing the protective structure was the main reason for non-adoption and has increased to $86.5 \%$ compared to $64.3 \%$ in the baseline survey. This is followed with the uncertainty on its financial gains (12.8\%) making them reluctant to adopt the technology. No available materials (5.0\%), no capital outlay (4.3\%), and lack of water or poor irrigation system (3.5\%) in the farm are the other reasons for not adopting the technology.

Table 16. Reason for not adopting Protective Structure

\begin{tabular}{|c|c|c|c|c|c|c|c|c|c|c|c|c|}
\hline \multirow{3}{*}{ Reason* } & \multicolumn{6}{|c|}{ Baseline } & \multicolumn{6}{|c|}{ Follow-Up } \\
\hline & \multicolumn{2}{|c|}{ Non-FFS } & \multicolumn{2}{|c|}{ FFS } & \multicolumn{2}{|c|}{ Total } & \multicolumn{2}{|c|}{ Non-FFS } & \multicolumn{2}{|c|}{ FFS } & \multicolumn{2}{|c|}{ Total } \\
\hline & $\mathrm{n}$ & $\%$ & $\mathrm{n}$ & $\%$ & $\mathrm{n}$ & $\%$ & $\mathrm{n}$ & $\%$ & $\mathrm{n}$ & $\%$ & $\mathrm{n}$ & $\%$ \\
\hline Due to added cost & 21 & 61.8 & 51 & 65.4 & 72 & 64.3 & 26 & 81.3 & 96 & 88.1 & 122 & 86.5 \\
\hline $\begin{array}{l}\text { Uncertainty on its financial } \\
\text { gains }\end{array}$ & 12 & 35.3 & 13 & 16.7 & 25 & 22.3 & 7 & 21.9 & 11 & 10.1 & 18 & 12.8 \\
\hline $\begin{array}{l}\text { The design of the structure is } \\
\text { not suitable in the local } \\
\text { condition }\end{array}$ & 3 & 8.8 & 4 & 5.1 & 7 & 6.3 & 2 & 6.3 & 1 & .9 & 3 & 2.1 \\
\hline $\begin{array}{l}\text { No available materials to be } \\
\text { used }\end{array}$ & 6 & 17.6 & 9 & 11.5 & 15 & 13.4 & 3 & 9.4 & 4 & 3.7 & 7 & 5.0 \\
\hline $\begin{array}{l}\text { Lack of water or due to poor } \\
\text { irrigation system in the farm }\end{array}$ & 4 & 11.8 & 4 & 5.1 & 8 & 7.1 & - & - & 5 & 4.6 & 5 & 3.5 \\
\hline No capital outlay & 5 & 14.7 & 5 & 6.4 & 10 & 8.9 & 3 & 9.4 & 3 & 2.8 & 6 & 4.3 \\
\hline No experience & 2 & 5.9 & - & - & 2 & 1.8 & 2 & 6.3 & - & - & 2 & 1.4 \\
\hline Due to unavailability of area & - & - & 2 & 2.6 & 2 & 1.8 & - & - & - & - & - & - \\
\hline lack of time & - & - & 1 & 1.3 & 1 & .9 & 1 & 3.1 & 2 & 1.8 & 3 & 2.1 \\
\hline lack of labor & - & - & 1 & 1.3 & 1 & .9 & - & - & 1 & .9 & 1 & .7 \\
\hline Observe first & - & - & 1 & 1.3 & 1 & .9 & - & - & 2 & 1.8 & 2 & 1.4 \\
\hline Just starting to plant & - & - & 3 & 3.8 & 3 & 2.7 & - & - & - & - & - & - \\
\hline No time to do it & - & - & 1 & 1.3 & 1 & .9 & - & - & 1 & .9 & 1 & .7 \\
\hline Location of the planting area & - & - & 1 & 1.3 & 1 & .9 & - & - & 2 & 1.8 & 2 & 1.4 \\
\hline Health problems & - & - & 1 & 1.3 & 1 & .9 & - & - & - & - & - & - \\
\hline Haven't planted vegetable yet & - & - & 1 & 1.3 & 1 & .9 & - & - & - & - & - & - \\
\hline
\end{tabular}


Survey on farm practices of small-scale vegetable farmers

\section{Farmer's Reasons for Discontinuing Vegetable Production}

We found out that some farmers who initially did vegetable farming during the baseline were no longer farming vegetables in the follow up survey. Table 17 below enumerates their reasons for no longer farming vegetables. Most are focused on other crops such as corn, rice, banana and coconut. Other farmers were discouraged because they were not able to harvest due to damaging effects of rain on their production. Others were employed as a public official or as service workers.

Table 17. Farmers reason why they did not continue vegetable farming (follow-up)

\begin{tabular}{lccc}
\hline \multicolumn{1}{c}{ Reason* } & Non-FFS & FFS & Total \\
\cline { 2 - 4 } & $n$ & $n$ & $n$ \\
\hline Focused on other crops (corn, rice, banana, coconut, others) & - & 8 & 8 \\
Employed as barangay official & - & 2 & 2 \\
Employed as service worker & 2 & - & 2 \\
Focused on fruit production & - & 1 & 1 \\
Focused on planting fruit trees & - & 1 & 1 \\
Not planting now because of the weather & - & 1 & 1 \\
The land used for vegetable farming were taken back by the owner & 1 & - & 1 \\
The wife attended the training. We're not able to harvest because of the rain the & - & 1 & 1 \\
fruits were damaged so we stopped & & & \\
We're not able to harvest because the crops were damaged by frequent rain. & - & 1 & 1 \\
Planned not to plant vegetable again and focus on rice farming due to old age & & & \\
and lack of labor & & & \\
*multiple response & &
\end{tabular}

\section{Gender Roles in Vegetable Farming}

Evaluating gender roles in farming is important in understanding the social structure involved in vegetable production. This section highlights the role of men and women in vegetable enterprise starting from the decision on what to crop up to marketing stage. Evaluating the role of men and women presents the household dynamics on decisions relating to vegetable production. The husband and wife were separately asked to indicate who decides or are involve in specific tasks. By asking them separately, we tried to reduce the bias associated when the husband and wife are present in one setting.

Table 18 shows that more than half of the respondents who attended trainings related to vegetable farming are males (58.40\%). In addition, result shows that mostly males dominate on the other tasks such as the decision on what to plant, raising seedling and land preparation. However, a consistent $20 \%$ of the respondents indicated that both male and female do these tasks. Male farmers are usually the one deciding what crop to plant $(58.30 \%)$, do the methods of raising seedlings (57.80\%), doing the seedbed preparation (72.20\%) and even tilling or land preparation $(76.80 \%)$. Nevertheless almost $20 \%$ of women farmers are the ones making planting decisions and raising seedlings. 
Seriño, Castillo \& Ruales

Table 18. Gender roles in attendance to trainings, decision on what to crop, raising seedling and land preparation

\begin{tabular}{lcccccccc}
\hline \multirow{2}{*}{ Gender } & \multicolumn{2}{c}{$\begin{array}{c}\text { Attendance to } \\
\text { trainings }\end{array}$} & \multicolumn{2}{c}{$\begin{array}{c}\text { Decides what crop to } \\
\text { plant }\end{array}$} & \multicolumn{2}{c}{$\begin{array}{c}\text { Raising } \\
\text { seedlings }\end{array}$} & \multicolumn{2}{c}{$\begin{array}{c}\text { Land preparations / } \\
\text { Tilling }\end{array}$} \\
\cline { 2 - 10 } & $\mathrm{n}$ & $\%$ & $\mathrm{n}$ & $\%$ & $\mathrm{n}$ & $\%$ & $\mathrm{n}$ & $\%$ \\
\hline Female & 20 & 22.5 & 19 & 22.6 & 16 & 19.3 & 3 & 3.7 \\
Male & 52 & 58.4 & 49 & 58.3 & 48 & 57.8 & 63 & 76.8 \\
Both & 17 & 19.1 & 16 & 19.0 & 19 & 22.9 & 16 & 19.5 \\
\hline
\end{tabular}

In terms of transplanting the seedlings and employing systems of irrigation, males tend to dominate these tasks. Almost half of the respondents $(48.80 \% \& 45 \%)$ indicated that men will usually do the transplanting and irrigation related works (Table 19) and only approximately $10-13 \%$ of women indicated they are involve in this tasks. Around $41.2 \%$ of the respondents indicated that transplanting and irrigation are shared by both men and women. The tasks of fertilizer application $(66.70 \%)$, pruning $(66 \%)$ and trellising $(70.80 \%)$ are still predominantly done by men but $20 \%$ of it is a shared responsibility and only $8-11 \%$ indicated its a woman's responsibility.

Table 19. Gender roles in transplanting, irrigation, fertilizer application, pruning and trellising

\begin{tabular}{lrrrrrrrrrr}
\hline \multirow{2}{*}{ Gender } & \multicolumn{2}{c}{ Transplanting } & \multicolumn{2}{c}{ Irrigation } & \multicolumn{2}{c}{ Fertilizer Application } & \multicolumn{2}{c}{ Pruning } & \multicolumn{3}{c}{ Trellising } \\
\cline { 2 - 12 } & $\mathrm{n}$ & $\%$ & $\mathrm{n}$ & $\%$ & $\mathrm{n}$ & \multicolumn{1}{c}{$\%$} & $\mathrm{n}$ & $\%$ & $\mathrm{n}$ & $\%$ \\
\hline Female & 8 & 10.0 & 11 & 13.8 & 7 & 9.3 & 6 & 11.3 & 5 & 7.7 \\
Male & 39 & 48.8 & 36 & 45.0 & 50 & 66.7 & 35 & 66.0 & 46 & 70.8 \\
Both & 33 & 41.2 & 33 & 41.2 & 18 & 24.0 & 12 & 22.6 & 14 & 21.5 \\
\hline
\end{tabular}

Table 20 shows that $51.4 \%$ and $73.1 \%$ of the respondents who do weeding, pest and disease control are men. For pest and disease control, it is $16.5 \%$ shared and $10.4 \%$ woman's responsibility. The task of harvesting is a shared responsibility $(67.1 \%)$, with $28.8 \%$ of farms a male responsibility. For almost half the farms men are deciding where to market the produce and taking it to the market $(46.7 \%$ \& $52.5 \%$, respectively) but for almost half the farms the woman is either taking the sole responsibility or sharing it.

Table 20. Gender roles in weeding, pest control, harvesting and marketing

\begin{tabular}{|c|c|c|c|c|c|c|c|c|c|c|}
\hline \multirow{2}{*}{ Gender } & \multicolumn{2}{|c|}{$\begin{array}{l}\text { Weed } \\
\text { Control }\end{array}$} & \multicolumn{2}{|c|}{$\begin{array}{c}\text { Pest and disease } \\
\text { Control }\end{array}$} & \multicolumn{2}{|c|}{ Harvesting } & \multicolumn{2}{|c|}{$\begin{array}{c}\text { Decides marketing } \\
\text { outlet }\end{array}$} & \multicolumn{2}{|c|}{$\begin{array}{c}\text { Bring produce to } \\
\text { market }\end{array}$} \\
\hline & $\mathrm{n}$ & $\%$ & $n$ & $\%$ & $\mathrm{n}$ & $\%$ & $n$ & $\%$ & $\mathrm{n}$ & $\%$ \\
\hline Female & 5 & 7.1 & 7 & 10.4 & 3 & 4.1 & 14 & 23.3 & 15 & 25.4 \\
\hline Male & 36 & 51.4 & 49 & 73.1 & 21 & 28.8 & 28 & 46.7 & 31 & 52.5 \\
\hline Both & 29 & 41.4 & 11 & 16.4 & 49 & 67.1 & 18 & 30.0 & 13 & 22.0 \\
\hline
\end{tabular}

Table 21 shows that activities related to record keeping and monitoring of sales is mostly dominated by females. As shown in Table $21,42.6 \%$ of the respondents who do the selling of the vegetables in the market are women, $27.9 \%$ share responsibility and $29.5 \%$ solely male. Although recording of farm activities is not 
commonly done by farmers, those who do keep records are mostly women (59.1\%). Taking into account the sales and the determination of profit gained from the production are dominantly done by women of about $75.4 \%$ and $44.7 \%$ of the respondents, respectively. These results corroborate with the Filipino culture that women mainly do the handling, saving and budgeting of money in the household.

Table 21. Gender roles in record keeping and monitoring the sales and profit from vegetable production

\begin{tabular}{lccrrrrrr}
\hline \multirow{2}{*}{ Gender } & \multicolumn{2}{c}{ Sell produce } & \multicolumn{2}{c}{$\begin{array}{c}\text { Record farm } \\
\text { activities }\end{array}$} & \multicolumn{2}{c}{$\begin{array}{c}\text { Taking sales into } \\
\text { account }\end{array}$} & \multicolumn{2}{c}{$\begin{array}{c}\text { Profit } \\
\text { determination }\end{array}$} \\
\cline { 2 - 8 } & \multicolumn{1}{c}{$\mathrm{n}$} & \multicolumn{1}{c}{$\mathrm{n}$} & \multicolumn{1}{c}{$\%$} & \multicolumn{1}{c}{$\mathrm{n}$} & \multicolumn{1}{c}{$\%$} & $\mathrm{n}$ & $\%$ \\
\hline Female & 26 & 42.6 & 13 & 59.1 & 43 & 75.4 & 21 & 44.7 \\
Male & 18 & 29.5 & 5 & 22.7 & 9 & 15.8 & 11 & 23.4 \\
Both & 17 & 27.9 & 4 & 18.2 & 5 & 8.8 & 15 & 31.9 \\
\hline
\end{tabular}

An open-ended question was also asked to respondents pertaining to the participation and roles of men and women in vegetable farming. According to them, men dominantly do the farming activities because they do the heavy work requiring more muscle strength such as tilling or land preparation, fertilizer application, trellising and bringing the produce to the market. Women participate only when lighter efforts and lesser muscle strength is needed such as harvesting, selling the produce, monitoring the sales and sometimes keeping records. Furthermore, women indicated that men are relatively faster in doing the farm activities than women. Women also have more time allocated to doing household activities, and attending to children's needs hence can only work in the farm when they have free time or when specifically requested. This suggests that for most farms women play a supportive role in vegetable farming.

\section{Estimated Impact of Farmer Field School on Vegetable Production}

\section{Changes in satisfaction in current production}

Figure 4 shows the changes in the level of satisfaction of farmers in their current production. We asked the farmers whether they are satisfied with their current vegetable production. In the baseline survey, we noticed that non-FFS group has higher level of satisfaction compared to the FFS group. However, in the follow up survey a different picture is observed. Figure 4 shows that FFS group has higher satisfaction in their production compared to the non-FFS group. This is a good indication of the positive change brought by the project intervention.

We compare the changes for both the FFS and non-FFS group. The figure below shows that there is rising satisfaction in vegetable production among FFS group compared to a declining satisfaction in the non-FFS group. 


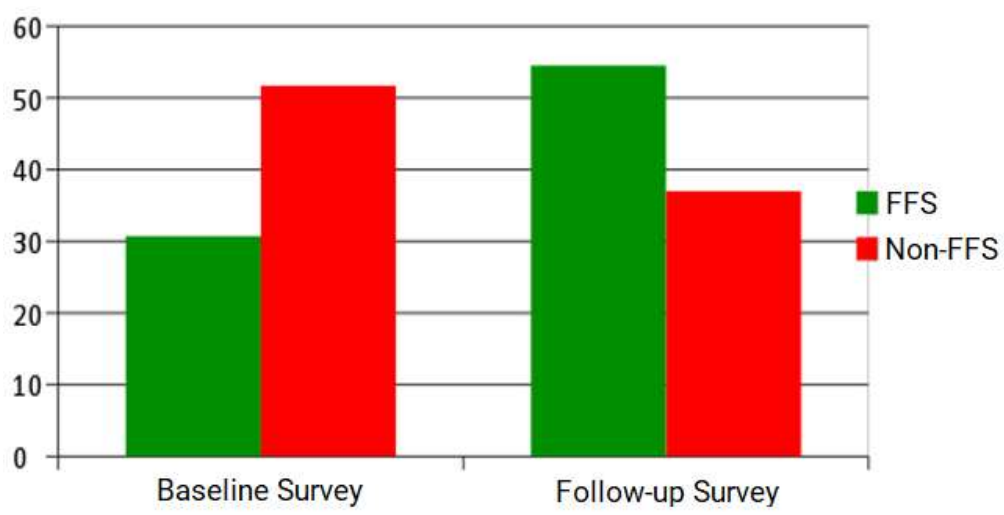

Figure 4. Changes in the degree of satisfaction of current vegetable production

\section{Changes in Farm Income}

Table 22 presents the different income sources of non-FFS and FFS farmers. The mean farm income of FFS farmers during the baseline survey is around PHP21,911.97. This farm income is estimated on a per farm per year basis. The farm size of the respondents devoted to vegetable production ranges from $400 \mathrm{~m}^{2}$ to $1,000 \mathrm{~m}^{2}$ with an average farm size of $770 \mathrm{~m}^{2}$. Compared to non-FFS the annual average farm income of FFS is a little bit less. However, the follow-up survey indicated that FFS farmers have relatively higher annual income compared to nonFFS group. On average the annual income of FFS farmers is around PHP32,936 while for the non-FFS the average annual income is only around PHP29,388.04.

If evaluating changes across time, the income of the FFS group increased from PHP21,911.97 to PHP32,936.65. This reflects around 50\% increase in annual farm income within the two-year period. This is a positive indication of the changes associated farmers improved knowledge, understanding and skill in managing vegetable production which translates to increased vegetable income or increased yield and quality of vegetables produced. It is also important to note that farmers do not solely rely their income on vegetable production. The table shows that their other sources of income is higher than the farm income.

Table 22. Annual income from different sources

\begin{tabular}{lcccccc}
\hline & \multicolumn{3}{c}{ Baseline } & \multicolumn{3}{c}{ Follow-up } \\
\cline { 2 - 7 } Income Sources & Non-FFS & FFS & Total & Non-FFS & FFS & Total \\
& Mean & Mean & Mean & Mean & Mean & Mean \\
\hline Farm Income & $22,709.79$ & $21,911.97$ & $22,310.88$ & $29,388.04$ & $32,936.65$ & $31,162.35$ \\
Other Income & $42,786.46$ & $38,198.67$ & $40,492.56$ & $74,225.47$ & $56,876.16$ & $65,550.81$ \\
\hline
\end{tabular}

\section{Difference-in-difference Computation}

The difference-in-difference is a widely used method to estimate the treatment effects by comparing the before- and after-treatment differences in the outcome of a beneficiary and a control group (FFS \& non-FFS farmers, respectively). In this study, the effect of on-farm income before and after the farmer field school among farmers is estimated and evaluated. Table 23 summarizes the changes in annual farm income of the respondents. 
Survey on farm practices of small-scale vegetable farmers

Table 23. Matrix of annual farm income of the respondents before and after project implementation

\begin{tabular}{lcc}
\hline Group & $\begin{array}{c}\text { Before Project Intervention (2015) } \\
\text { (Baseline) }\end{array}$ & $\begin{array}{c}\text { After Project Intervention } \\
\text { (2017) (Follow up) }\end{array}$ \\
\hline FFS (Beneficiaries) & PHP21,911.97 & PHP32,936.65 \\
Non-FFS (Non-beneficiaries) & PHP22,709.79 & PHP29,388.04 \\
\hline
\end{tabular}

Algebraic Approach

$$
\begin{aligned}
\text { Effect on Farm Income } & =\text { Difference }_{\text {AFTER }}-\text { Difference }_{\text {BEFORE }} \\
& =(32,936.65-29,388.04)-(21,911.97-22,709.79) \\
\text { Effect on Farm Income } & =\text { PHP4,346.43 }
\end{aligned}
$$

Before the project intervention, FFS farmers have lower mean farm income amounting to PHP21,911.97 compared to non-FFS farmers with an average annual income of PHP22,709.79. During the follow up survey, both the income of non-FFS and FFS farmers have increased with time but the increased in income among FFS is higher compared to non-FFS farmers. On average, the FFS farm income during the follow up survey is around PHP32,936.65 while for the non-FFS farmers the average income isPHP29,388.04.

The inclusion of non-FFS group will serve as our counterfactual presenting the scenario of what could have happened without the project intervention. The algebraic computation above shows the estimated impact of integrated crop management intervention in vegetable production among small-scale farmers. The difference-in-difference results show that the estimated impact of the project on farm income is around PHP4,346.43 per year per farm. This implies that the training generates a positive impact on the livelihood of farmers.

\section{SUMMARY AND CONCLUSION}

This study aimed to collect data on the practices of small-scale vegetables farmers in the Bohol, Leyte and Samar. The respondents of the survey include farmers that have been identified to participate in the farmer field school (FFS). We also randomly selected non-FFS farmers to serve as control group for the study. The baseline findings show that FFS farmers and non-FFS farmers do not largely differ in their farming practices.

The top eight major vegetable crops planted by both non-FFS and FFS farmers include eggplant, bitter gourd, beans, sweet pepper, pechay, squash, tomato and okra (lady finger). The methods of raising seedlings vary according to the crops planted. Majority of the farmers till their land as part of the land preparation and used draft-animal powered way of tilling. The average distance of the farms of nonFFS and FFS respondents to the market outlets is close to $10 \mathrm{~km}$ with an estimated travelling time of around $26 \mathrm{~min}$. The vegetable products are mostly delivered to buyer. 
More than half of the non-FFS farmers are satisfied of their production output while only 32 percent of FFS are satisfied of their current output but higher percentage of FFS farmers believe that in the next five years their production output will improve considerably. Many farmers are aware and willing to adopt protected cultivation but only very few actually adopted the technology mainly because of the added cost and uncertainty in its financial gains. For the follow-up survey, there is a noticeable increase in level of satisfaction in vegetable production among the FFS group. This suggests that the project was able to encourage vegetable production among farmers trained under the farmer field school compared to the non-FFS group.

All the farming activities are shared between men and women, and on some farms can be solely a male or a female responsibility. The labor intensive activities in vegetable farming such as land preparation, irrigation, trellising and bringing products to the market were a male responsibility on most farms. Whereas record keeping and sales monitoring were a female responsibility on most farms. Harvesting was the most widely shared responsibility among the survey respondents. Results suggest that there is benefit in training both men and women in all vegetable farming activities.

In terms of farm income, FFS group has relatively lower average income compared to the non-FFS group in the baseline scenario. However, the situation changed in the follow up survey. The FFS group now has higher income compared to the non-FFS group. The changed in household farm income among FFS group is around $50 \%$. This is a positive indication of the benefits brought by the project. In terms of impact, the method of difference in difference shows that the impact of farmer field school generates an increase in farm income by PHP4,346.43 per year per farm. Given the follow-up survey is only two years after the baseline, the changed in income can be considered as a short-term impact of the project. It is further recommended to do another impact assessment two or three years after the project completion. Aside from economic impact, other factors can also be evaluated such as environmental and social aspects in assessing the impacts of the project.

\section{ACKNOWLEDGMENT}

This study has been supported by ACIAR and the Visayas State University (VSU). We would like to acknowledge the financial support from ACIAR. The cooperation of other project collaborators, LGU's, farmer respondents and enumerators are gratefully acknowledged. Also the active participation of BISUBilar, NWSSU, Landcare Philippines and Eastwest Seed Company enormously helped the conduct of this study. 
Survey on farm practices of small-scale vegetable farmers

\section{REFERENCES}

Armenia PT, Bulayog MSB, Pantindol TR, Seriño MNV \& Glova NM. 2012. SocioEconomic Baseline for the REDD+ Project Sites in Southern Leyte, Philippines. Deutsche Gesellschaft für Internationale Zusammenarbeit (GIZ) $\mathrm{GmBH}$, November 2011

Armenia PT, Menz KM, Rogers GS, Gonzaga Z, Gerona R \& Tausa ER. 2013. Economics of vegetable production under protected cropping structures in the Eastern Visayas, Philippines. In Oakeshott J and Hall D (eds) Smallholder HOPES- horticulture, people and soil. Proceedings of the ACIAR-PCAARD Southern Philippines Fruits and Vegetables Program meeting, 3 July 2012, Cebu, Philippines, ACIAR Proceedings 139

Conception S, Dagupen K, Lizada MC \& Prior RM. 2007. The Vegetable Industry in the Philippines. Australia: Australian Centre for International Agricultural Research

GMA News TV. 2013, July 6. Vegetable prices to rise during rainy season - DA. Retrieved December 16, 2016, from GMA News TV: http://www.gmanetwork. com/news/story/316208/money/vegetable-prices-to-rise-during-rainyseason-da

Gonzaga Z, Capuno O, Loreto M, Gerona R, Borines L, Tulin A, Mangmang JS, Lusanta DC, Dimabuyu \& Rogers GS. 2013. Low-cost protected cultivation: enhancing year-round production of high-value vegetables in the Philippines (pp123-137). Australia: Australian Centre for International Agricultural Research

McClintock A, Preciados L, Orr L \& Bulayog S. 2012. Economic Impacts of Component 2: Protected Cropping Technology for Vegetable Production in the Southern Philippines, Economic Research Report No. 48 (pp1-92). NSW Trade and Investment

Philippine Statistical Authority (PSA). 2016. CountrySTAT Philippines. Retrieved December 16, 2016, from http://countrystat.psa.gov.ph/ 